Virginia Woolf: The Novels 


\section{ANALYSING TEXTS}

General Editor: Nicholas Marsh

Chaucer: The Canterbury Tales Gail Asbton Shakespeare: The Tragedies Nicholas Marsh

Virginia Woolf: The Novels Nicholas Marsh

Jane Austen: The Novels Nicholas Marsh

Thomas Hardy: The Novels Norman Page

Further titles are in preparation 


\title{
Virginia Woolf: The Novels
}

\author{
NICHOLAS MARSH
}

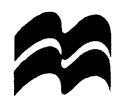

Macmillan Education 


\section{$\infty$}

VIRGINIA WOOLF

Copyright (C) 1998 by Nicholas Marsh

Softcover reprint of the hardcover 1st edition 1998 978-0-333-73931-0

All rights reserved. No part of this book may be used or reproduced in any manner whatsoever without written permission except in the case of brief quotations embodied in critical articles or reviews.

For information, address:

St. Martin's Press, Scholarly and Reference Division, 175 Fifth Avenue, New York, N.Y. 10010

First published in the United States of America in 1998

This book is printed on paper suitable for recycling and made from fully managed and sustained forest sources.

ISBN 978-0-333-68349-1 ISBN 978-1-349-26322-6 (eBook)

DOI 10.1007/978-1-349-26322-6

Library of Congress Cataloging-in-Publication Data

Marsh, Nicholas.

Virginia Woolf, the novels / Nicholas Marsh.

p. cm. - (Analysing texts)

Includes bibliographical references and index.

ISBN 978-0-312-21374-9(cloth). - ISBN 978-0-312-21375-6(paper)

1. Woolf, Virginia, 1882-1941-Criticism and interpretation.

2. Women and literature-England-History-20th century. 3. Woolf, Virginia, 1882-1941 - Outlines, syllabi, etc. I. Title.

II. Series.

PR6045.O72Z81525 1998

$823 ' .912-\mathrm{dc} 21$ 
For Georgie 


\section{Contents}

General Editor's Preface

page $\mathrm{x}$

A Note on Editions

$\mathrm{xi}$

Part 1: Analysing Virginia Woolf's Novels

1 Virginia Woolf's style

Mrs Dalloway, pp. 34-5

To the Lighthouse, pp. 106-7

The Waves, p. 15

Conclusions

Methods of Analysis

Suggested Work

2 Mental Processes in Virginia Woolf 19

Mrs Dalloway, pp. 43-5 20

To the Lighthouse, pp. 57-9 28

The Waves, pp. 179-81 36

Conclusions 43

Methods of Analysis $\quad 45$

Suggested Work $\quad 47$

3 Male and Female in Virginia Woolf 48

Mrs Dalloway, pp. 17-19 48

To the Lighthouse, pp. 114-15 53

The Waves, pp. 17-19 59

Conclusions 65

Methods of Analysis $\quad 67$

Suggested Work 68

4 Social Commentary and Satire 69

Mrs Dalloway, pp. 13-14 70

To the Lighthouse, pp. 194-5 75

The Waves, pp. 169-71 79

Conclusions $\quad 86$ 
Methods of Analysis $\quad 87$

Suggested Work $\quad 88$

5 Imagery and Symbol 89

Imagery: Similes and Metaphors $\quad 89$

Imagery: Symbolism 90

Imagery in the Novels 91

Mrs Dalloway, p. 44; and Peter Walsh's Knife 92

To the Lighthouse, the Boar's Head, and the

Lighthouse 95

The Waves, pp. 153-4 102

The Sea and Water in To the Lighthouse and The Waves 106

Conclusions 113

Methods of Analysis $\quad 114$

Suggested Work 115

6 The Significance of Nature 117

Mrs Dalloway, pp. 164-5 119

To the Lighthouse, pp. 132-3 124

The Waves, pp. 157-8 130

Conclusions 136

Methods of Analysis 139

Suggested Work 140

7 Life and Art $\quad 142$

Origins in Human Nature $\quad 143$

Learning, Reason and Poetry 147

Art: Lily Briscoe's Painting 156

Art and the Structure of Virginia Woolf's Novels $\quad 167$

Part 2: The Context and the Critics 171

8 Virginia Woolf's Life and Work 173

Virginia Woolf's Life $\quad 174$

Virginia Woolf's Writings $\quad 178$

The Development of Themes in Virginia Woolf's Work 
9 Virginia Woolf's Contribution to the Development of the Novel

Virginia Woolf's Approach to the Novel 186

Virginia Woolf's Contribution to the Novel 191

The 'New' Subject-matter: Psychology and Feminism 194

10 A Sample of Critical Views 196

Erich Auerbach 196

Elizabeth Abel 205

Gillian Beer 213

Further Reading $\quad 218$

Index $\quad 222$ 


\section{General Editor's Preface}

This series is dedicated to one clear belief: that we can all enjoy, understand and analyse literature for ourselves, provided we know how to do it. How can we build on close understanding of a short passage, and develop our insight into the whole work? What features do we expect to find in a text? Why do we study style in so much detail? In demystifying the study of literature, these are only some of the questions the Analysing Texts series addresses and answers.

The books in this series will not do all the work for you, but will provide you with the tools, and show you how to use them. Here, you will find samples of close, detailed analysis, with an explanation of the analytical techniques utilised. At the end of each chapter there are useful suggestions for further work you can do to practise, develop and hone the skills demonstrated and build confidence in you own analytical ability.

An author's individuality shows in the way they write: every work they produce bears the hallmark of that writer's personal 'style'. In the main part of each book we concentrate therefore on analysing the particular flavour and concerns of one author's work, and explain the features of their writing in connection with major themes. In Part 2 there are chapters about the author's life and work, assessing their contribution to developments in literature; and a sample of critics' views are summarised and discussed in comparison with each other. Some suggestions for further reading provide a bridge towards further critical research.

Analysing Texts is designed to stimulate and encourage your critical and analytic faculty, to develop your personal insight into the author's work and individual style, and to provide you with the skills and techniques to enjoy at first hand the excitement of discovering the richness of the text.

NiCHOLAS MARSH 


\section{A Note on Editions}

References to the three novels studied in this book, Mrs Dalloway, To the Lighthouse and The Waves, are page references to the Vintage editions of 1992, published by Vintage Books (Random House), and based on the Hogarth Press editions of 1990. 